\title{
Topolins and Red Light Improve the Micropropagation Efficiency of Passion Fruit (Passiflora edulis Sims) 'Tainung No. 1'
}

\author{
Ying-Chun Chen and Chen Chang \\ Department of Horticulture, National Chung Hsing University, 145 Xingda \\ Road, South District, 402 Taichung, Taiwan, Republic of China
}

\author{
Huey-Ling Lin \\ Department of Horticulture and Innovation and Development Center of \\ Sustainable Agriculture (IDCSA), Orcid 0000-0001-5305-8095, National \\ Chung Hsing University, 145 Xingda Road, South District, 402 Taichung, \\ Taiwan, Republic of China
}

Additional index words. Passiflora edulis, aromatic cytokinins, LEDs, propagation, in vitro

\begin{abstract}
Passion fruit is a commercial crop of economic importance worldwide, with recent increases in demand for high-quality plants for commercial production. Plant tissue culture is widely used for the mass propagation of many commercial crops, however its application on passion fruit is challenged by the problem of low reproducibility, leaf chlorosis, and growth retardation resulted from in vitro culture. The aim of this study was to evaluate the effects of cytokinins and light quality on in vitro culture of nodal segments of passion fruit 'Tainung No. 1'. Three aromatic cytokinins were tested in a modified MS basal medium. The bud proliferation rates of segments initiated on a media containing $1 \mathrm{mg} \cdot \mathrm{L}^{-1}$ meta-topolin riboside $(m \mathrm{TR})$ or benzyladenine $(\mathrm{BA})$ were not significantly different at the same concentration. Buds cultured on medium supplemented with $m$ TR grew and elongated for 4 weeks, while buds on a medium containing BA formed rosettes. After transfer to a medium without plant growth regulators (PGRs), shoots rooted spontaneously within 8 weeks. Furthermore, the effects of continuous propagation under a high proportion of red light affected the subsequent plant growth. Red LED induced an increase in the chlorophyll content $\left(2.71 \mathrm{mg} \cdot \mathrm{g}^{-1}\right)$ compared with other light qualities $\left(1.05-2.63 \mathrm{mg} \cdot \mathrm{g}^{-1}\right)$ and improved plantlet quality. Acclimated plants were grown in the field, and the flower morphology and fruit set were of commercial quality. Findings showed that replacing BA with $m$ TR as the main cytokinin and using a high proportion of red light during the tissue culture induction period produced highquality plantlets in 3 months. This system is economical and will be further developed for the commercial propagation of passion fruit vines in the future.
\end{abstract}

The genus Passiflora L. is a group of about 520 species that grow as vines, shrubs, or small trees in tropical, subtropical, and occasionally temperate areas (Ulmer and MacDougal, 2004). Also known as passion flowers, numerous species in this genus are economically important because of the taste and nutritional value of their fruits (i.e.,

\footnotetext{
Received for publication 10 Apr. 2020. Accepted for publication 10 July 2020 .

Published online 10 July 2020.

This work was supported by grants from the Ministry of Science and Technology, Taiwan, Republic of China (Most 103-2313-B-005-004-; Most 1072321-B-005-007-)

We thank Dr. Yung-I Lee, National Museum of Natural Science, for access to the LED instrument used in this study.

H.-L.L. is the corresponding author. E-mail: hllin@ dragon.nchu.edu.tw.

This is an open access article distributed under the CC BY-NC-ND license (https://creativecommons. org/licenses/by-nc-nd/4.0/).
}

passion fruit), the pharmaceutical properties of their leaves, or the ornamental value of their flowers (Huh et al., 2017; Mikovski et al., 2019).

Passiflora species are propagated through seeds, cuttings, air-layering, or grafts (Faleiro et al., 2019; Ragavendran et al., 2012). In Taiwan, the main cultivar is Tainung No. 1, a hybrid of Passiflora edulis and P. edulis $\mathrm{f}$. flavicarpa. 'Tainung No.1' is conventionally propagated by grafting, but this method does not provide enough planting materials to satisfy the ever-increasing demand for international plants export. Therefore, an in vitro culture technique should be established to clone this superior genotype.

Tissue culture of Passiflora species could be used to mass produce healthy plantlets for commercial growers and to produce ornamental hybrids through somatic hybridization, to produce medicinal and secondary metabolites, and for in vitro conservation. Among the in vitro culture systems, organogenesis is the primary pathway for regener- ation of Passiflora (Mikovski et al., 2019; Otoni et al., 2013). For some medicinal Passiflora spp., there are reported callus culture systems and micropropagation protocols, while in vitro techniques have been discussed for conservation (Ożarowski, 2011; Ożarowski and Thiem, 2013; Pacheco et al., 2016). Nevertheless, micropropagation of Passiflora is not yet commercially feasible because adult material does not work well as an initial explant and has a low proliferation rate (Rocha et al., 2020). Furthermore, for each species within the genus, the reported culture conditions vary and each need to be optimized to overcome inherent tissue culture-induced problems, such as leaf chlorosis and growth retardation, and to increase production (Monteiro et al., 2000).

Cytokinins are a class of plant growth regulators widely used in Passiflora tissue culture. Benzyladenine (BA) is usually used for adventitious shoot induction and axillary shoot proliferation. The BA concentration should be reduced to enhance further elongation of shoot buds (Ożarowski and Thiem, 2013; Rocha et al., 2015). However, when BA is used in tissue culture for many plants, it is known to cause in vitro abnormalities, including hyperhydricity, shoot-tip necrosis, difficulty in rooting and acclimatization, and histogenic instability, in species as varied as Aloe polyphylla (Bairu et al., 2007), Beta vulgaris (Kubalákova and Strnad, 1992), Barleria greenii (Amoo et al., 2011), Hordeum vulgare (Huyluoglu et al., 2008), Magnolia spp. (Parris et al., 2012), Petunia (Bogaert et al., 2006), and 'Williams' banana (Bairu et al., 2008).

Meta-topolin $(m \mathrm{~T})$, or 6-(3-hydroxybenzylamino)-purine, first isolated from poplar leaves (Populus ×canadensis Moench., cv. Robusta), was shown to have a stronger cytokinin activity and may be useful as an alternative to BA (Mok et al., 2005; Mutui et al., 2012; Ornellas et al., 2017; Strnad et al., 1997). Exogenously applied $m \mathrm{~T}$ delayed chlorophyll degradation in excised radish cotyledons (Palavan-Ünsal et al., 2002a) and wheat leaves (Palavan-Ünsal et al., 2002b; Palavan-Ünsal et al., 2004), increased the in vitro-shoot multiplication rate of Aloe ferox (Bairu et al., 2009) and Pelargonium sidoides (Moyo et al., 2012), reduced shoot-tip necrosis in micropropagated Harpagophytum procumbens (Bairu et al., 2011) and Ulmus glabra (Mirabbasi and Hosseinpour, 2014), and reduced senescence in in vitro-propagated rose (Bogaert et al., 2006) and Pelargonium $\times$ hortorum cuttings (Mutui et al., 2012). The application of meta-topolin riboside ( $m \mathrm{TR}$ ) induced a higher chlorophyll $\mathrm{a} / \mathrm{b}$ ratio in banana shoottip culture (Aremu et al., 2012b). Also, $m \mathrm{~T}$ treated regenerants showed better in vitro rooting rates and acclimatization (Aremu et al., 2012a; Gentile et al., 2014). To the best of our knowledge, there have been no reports evaluating $m \mathrm{~T}$ and/or $m \mathrm{TR}$ in the currently used Passiflora in vitro culture protocols or on how they affect the micropropagation efficiency. 
The influence of light in regulating plant growth and development has been well documented. Using light-emitting diodes (LEDs) as the light source has been found to have positive effects on in vitro shoot and root development of various species, resulting in improved adaptability and growth after transfer to soil (Gupta and Agarwal, 2017). Over the decades, the use of monochromatic red and blue LEDs alone or in combination has been reported during plant morphogenesis both in vivo and in vitro (Agarwal and Dutta Gupta, 2016; Batista et al., 2018; Bula et al., 1991; Dutta Gupta and Jatothu, 2013; Gupta and Agarwal, 2017; Lee et al., 2011; Massa et al., 2008; Ramírez-Mosqueda et al., 2016). However, the effects of different and combined LED light qualities during in vitro culture of Passiflora has not been reported.

In this study, we determined the effects of aromatic cytokinins (BA, $m \mathrm{~T}$, and $m \mathrm{TR}$ ) and LED light qualities [blue (B), green $(\mathrm{G})$, red (R), and infrared (IR), singly and in combination] on direct bud multiplication, elongation, and rooting of the Tainung No. 1 cultivar of passion fruit. The optimized propagation system was efficient and amenable to large-scale vegetative production.

\section{Materials and Methods}

Plant material, disinfection, initial culture, and culture conditions. The Passiflora hybrid cultivar Tainung No. 1 was cultured in the greenhouse (Horticultural Experiment Station, National Chung Hsing University). During the cultivation period, the average annual temperature was $25.3{ }^{\circ} \mathrm{C}$ with an average relative humidity of $66.9 \%$, and the daily average maximum and minimum temperatures were 32.9 and $17.6{ }^{\circ} \mathrm{C}$, respectively. Nodal segments containing axillary buds were cut off from mature vines as explants for initial in vitro culture. Explants were surface-disinfected using $2 \%$ sodium hypochlorite $(\mathrm{NaOCl})$ and 1-2 drops of Tween 20 for $20 \mathrm{~min}$, and then washed in distilled water three times in a laminar flow hood. Nodal segment with a single bud was placed vertically into a test tube $(20 \times 150 \mathrm{~mm}$; PYREX Glass Test Tube No. 9820) containing $9 \mathrm{~mL}$ of a shoot induction medium (SI medium), which consisted of MS basal salts and vitamins (Murashige and Skoog, 1962), 100 $\mathrm{mg} \cdot \mathrm{L}^{-1}$ myo-inositol (Sigma-Aldrich Co.), $170 \mathrm{mg} \cdot \mathrm{L}^{-1} \mathrm{NaH}_{2} \mathrm{PO}_{4}$ (Hayashi Pure Chemical Ind., Co., Ltd., Japan), and 30 g. $\mathrm{L}^{-1}$ sucrose (Taiwan Sugar Corporation, Taiwan) and was solidified using $0.86 \%$ agar (Trade Mark, Taiwan). An initial experiment was conducted using various concentrations of benzyladenine (BA; $0,0.1,0.2$, and $1 \mathrm{mg} \cdot \mathrm{L}^{-1}$, Sigma-Aldrich Co.) and $\alpha$-naphthalene acetic acid (NAA; 0 and $0.1 \mathrm{mg} \cdot \mathrm{L}^{-1}$, SigmaAldrich Co.). We added BA and NAA to the medium before the $\mathrm{pH}$ was adjusted to 5.7 with $1 \mathrm{~N} \mathrm{HCl}$ or $\mathrm{NaOH}$ before autoclaving $\left(1.2 \mathrm{~kg} / \mathrm{cm}^{2}\right.$ of pressure, $\left.121{ }^{\circ} \mathrm{C}, 20 \mathrm{~min}\right)$. Explants were maintained at $25 \pm 1{ }^{\circ} \mathrm{C}$ under a 12-h photoperiod at a light intensity of 55.6 $\mu \mathrm{mol} \cdot \mathrm{m}^{-2} \cdot \mathrm{s}^{-1}$ (daylight fluorescent tubes FL-
30D/29, 40 w; China Electric Co, Taipei, Taiwan). Each treatment included 10 test tubes, which considered individual replications. The experiments were repeated three times.

After 4 weeks of culturing, elongated shoots were transferred to the plant growth regulator (PGR)-free PA2L medium, which contained MS salts and vitamins, $100 \mathrm{mg} \cdot \mathrm{L}^{-1}$ myo-inositol, $170 \mathrm{mg} \cdot \mathrm{L}^{-1} \mathrm{NaH}_{2} \mathrm{PO}_{4}, 20 \mathrm{~g} \cdot \mathrm{L}^{-1}$ sucrose, $1 \mathrm{~g} \cdot \mathrm{L}^{-1}$ peptone, $1 \mathrm{~g} \cdot \mathrm{L}^{-1}$ activated charcoal, $150 \mathrm{~mL} \cdot \mathrm{L}^{-1}$ coconut water $(\mathrm{KOH}$; BABI Corp International, Thailand), $6 \mathrm{~g} \cdot \mathrm{L}^{-1}$ potato powder (PhytoTechnology Laboratories), was solidified using $0.86 \%$ agar, and a $\mathrm{pH}$ adjusted to 5.2 before autoclaving. The other culture conditions were the same as above.

Effects of BA, meta-topolin ( $m T)$, and metatopolin riboside $(m T R)$ on proliferation and elongation of nodal segments. To test if the shoot quality could be improved by substituting another aromatic cytokinin for the BA, $m \mathrm{~T}$ (OlChemIm Ltd., Czech Republic) and $m$ TR (OlChemIm) were considered as targets. In the initial experiment, the best bud growth was seen with $1 \mathrm{mg} \cdot \mathrm{L}^{-1} \mathrm{BA}$ and $0.1 \mathrm{mg} \cdot \mathrm{L}^{-1} \mathrm{NAA}$, and this was thus used as the control to compare with substitution of $1 \mathrm{mg} \cdot \mathrm{L}^{-1} m \mathrm{~T}$ or $m \mathrm{TR}$. While the BA and NAA were added to the SI medium before autoclaving, the $m \mathrm{~T}$ and $m \mathrm{TR}$ were sterilized through a $0.22-\mu \mathrm{m}$ MFMillipore Membrane Filter (Merck, Ireland) before one was added to the autoclaved SI medium supplemented with NAA. Plantlets derived from initial culture on the PA2L medium were cut into nodal segments as explants to clarify the effects of the three cytokinins on bud multiplication and elongation.

Light quality affects plantlet growth and chlorophyll content of explants during in vitro culture. A custom system (Fig. 1A) designed for tissue-cultured plantlets and equipped with eight sets of LEDs (Nano Bio Light Technology Co., Ltd., Taiwan) as light sources (Chen et al., 2016; Fang et al., 2011; Lai et al., 2018) was used to test the influence of light quality on the growth of nodal segments. Eight sets of LED chips were mounted on the lips of the tissue culture vessels in a combination of blue (B), green $(\mathrm{G})$, red (R), and infrared (IR) LEDs. Each vessel had the same photosynthetic photon flux density, $42 \mu \mathrm{mol} \cdot \mathrm{m}^{-2} \cdot \mathrm{s}^{-1}$. The LED peaks for $\mathrm{B}, \mathrm{G}, \mathrm{R}$, and IR were $450 \pm 2 \mathrm{~nm}, 525 \pm 3$ $\mathrm{nm}, 660 \pm 5 \mathrm{~nm}$, and $730 \pm 5 \mathrm{~nm}$, respectively. Two different $\mathrm{B} / \mathrm{G} / \mathrm{R} / \mathrm{IR}$ ratios were used to produce either cool white light (26:26:26:2) or warm white light $(10: 45: 51: 4)$ with a spectrum like daylight. Four LED sets had chip ratios of 3B:3R:3IR, 1B:1G:7R, 1B:7R:1IR, and $1 \mathrm{~B}: 8 \mathrm{R}$. The other two sets had only one band each, namely 9R and 9B (Lai et al., 2018). The light spectrum of each set is shown in Fig. 1B. Five nodal segments were vertically cultured in one vessel containing SI medium with $1 \mathrm{mg} \cdot \mathrm{L}^{-1} \mathrm{mTR}$ and $0.1 \mathrm{mg} \cdot \mathrm{L}^{-1} \mathrm{NAA}$ (based on the results of the second experiment, above), with three vessels for each of the eight light quality combinations. After 4 weeks of culturing, the vessels were removed from the LED system. In the laminar flow hood, the nodal segments were examined and the bud numbers, leaf numbers, tendril numbers, and callus formation rate were recorded. These explants were then subcultured to the PA2L medium and moved to the culture room with the same conditions under fluorescent lights as described above. After 8 weeks of additional culture under fluorescent lights, the height, bud, and root numbers, and chlorophyll content of the plantlets were measured. Plant height was measured by a ruler after the taking out of the flask. The average numbers of bud and roots were counted for six plantlets. For the analysis of chlorophyll concentration, three leaf discs ( $8 \mathrm{~mm}$ in diameter) from each plant were collected and extracted with $5 \mathrm{~mL} \mathrm{~N}, \mathrm{~N}$ Dimethylformamide (DMF) for $24 \mathrm{~h}$ at $4{ }^{\circ} \mathrm{C}$ in darkness, following the protocol of Moran and Porath (1980). The absorbance was measured with a spectrophotometer (U2000; Hitachi, Japan) at 664.5 and $647.0 \mathrm{~nm}$, respectively. The concentrations of chlorophyll $\mathrm{a}$ and chl $\mathrm{b}$ were calculated using the formula described by Inskeep and Bloom (1985).

Acclimatization and transplantation. After subculture in the PA2L medium for 8 weeks, plantlets with well-developing roots and shoots (measuring $\approx 5 \mathrm{~cm}$ from the base of the shoot to the shoot tip) were planted in 6-inch plastic pots containing peatmoss (Klasmann-Deilmann GmbH, Germany) and covered by plastic wrap with several holes for about 2 weeks in a temperature gradient incubator (TG3; FIRSTEK, Taiwan) at $25^{\circ} \mathrm{C}$. The plantlets were then moved to a mist bed for another 2 weeks. Surviving plantlets were individually transferred to black plastic pots and cultured in the greenhouse.

Statistical analysis. All experiments were arranged in a completely randomized design (CRD). Statistical analysis was conducted using the SAS 9.4 software (Institute Inc., NC). The data, expressed as percentages, were transformed using arc sine before an analysis of variance (ANOVA) and converted back to original scale (Compton, 1994). Data were subjected to ANOVA, and differences between mean values among treatments were tested using least significant difference multiple range tests at a 5\% level of significance $(P \leq 0.05)$.

\section{Results and Discussion}

Effects of BA, meta-topolin (mT), and meta-topolin riboside (mTR) on nodal segment induction in tissue culture. BA is the most used cytokinin for the micropropagation of Passiflora, although some side effects, such as leaf chlorosis and retarded growth, have been reported (Monteiro et al., 2000). To determine if a topolin-type cytokinin could be substituted for BA, we first compared a proliferation media containing a range of BA concentrations. In medium without PGRs, only $8.1 \%$ of the buds elongated; while in medium with only $0.1 \mathrm{mg} \cdot \mathrm{L}^{-1} \mathrm{NAA}$, only $11.4 \%$ elongated. Additionally, the browning rates were higher than on media 

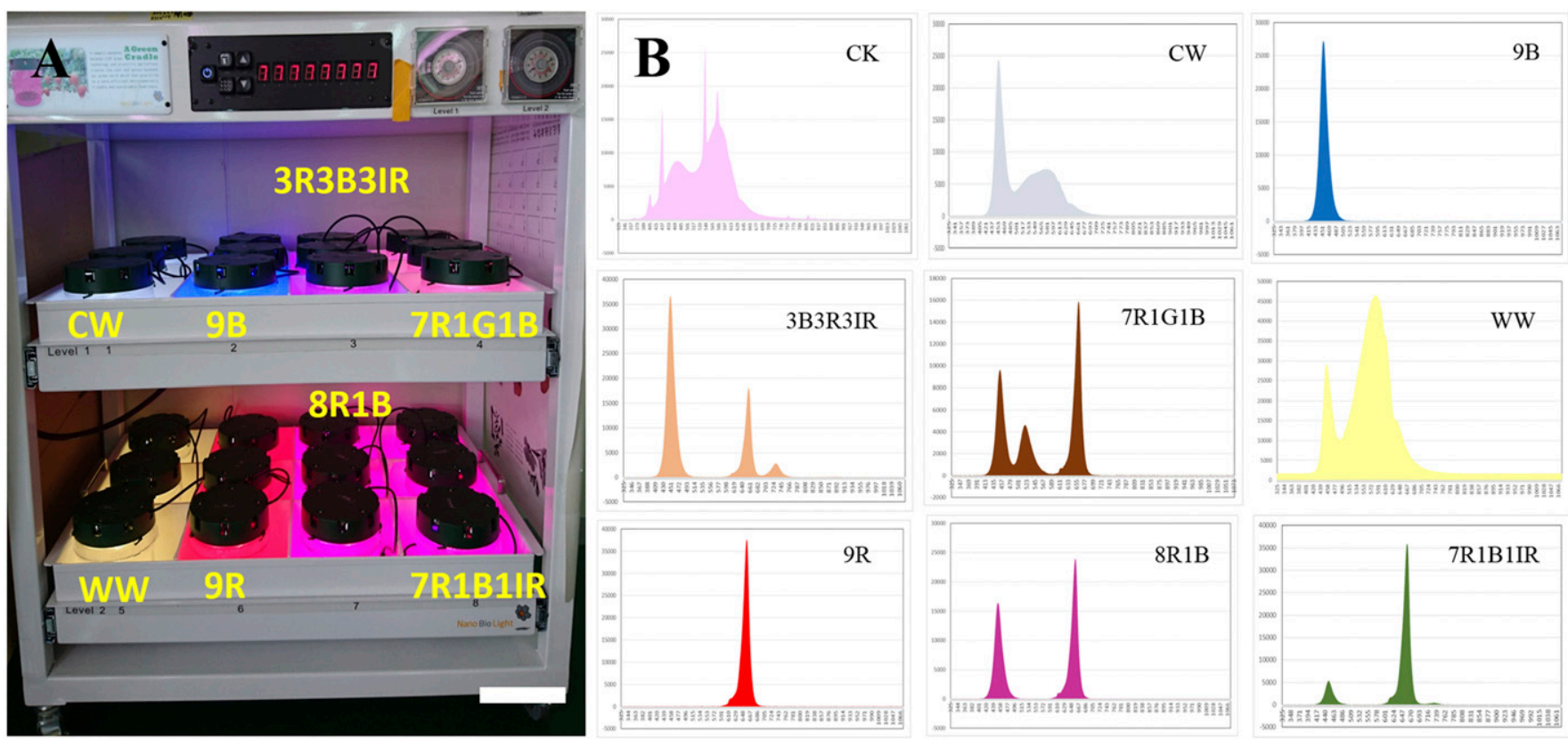

Fig. 1. The custom LED system (Mini E Light) equipped with eight sets of LEDs as light sources for nodal segment culture. (A) The system has two layers and 12 vessels per layer. Each layer has an independent timer to control day/night light cycle and light quantity $(\mathrm{bar}=10 \mathrm{~cm})$. (B) Spectral distribution of LEDs and fluorescent lamps. The spectral irradiance was recorded with a spectroradiometer and software system (FieldSpec HandHeld, ASD Inc. CO). B = blue light $(450 \pm 2 \mathrm{~nm}) ; \mathrm{G}=$ green light $(525 \pm 3 \mathrm{~nm}) ; \mathrm{R}=$ red light $(660 \pm 5 \mathrm{~nm}) ; \mathrm{IR}=\operatorname{infrared}(730 \pm 5 \mathrm{~nm}) ; \mathrm{CW}=$ cool white light [26:26:26:2 (B:G:R:IR)]; WW = warm white light [10:45:51:4 (B:G:R:IR)]. CK = fluorescent lamps in a tissue culture room.

Table 1. Effects of BA and NAA on the culture of nodal segments of passion fruit cultivar Tainung No. 1.

\begin{tabular}{|c|c|c|c|c|c|}
\hline $\mathrm{BA}\left(\mathrm{mg} \cdot \mathrm{L}^{-1}\right)^{\mathrm{z}}$ & NAA $\left(m g \cdot L^{-1}\right)$ & Bud sprouting $(\%)^{y}$ & Bud multiplication (\%) & Callus formation (\%) & Bud browning (\%) \\
\hline$\overline{0.0}$ & 0.0 & $8.1 \pm 4.2 \mathrm{c}$ & $0.0 \pm 0.0 \mathrm{~b}$ & $16.2 \pm 8.5 \mathrm{a}$ & $75.7 \pm 12.7 \mathrm{a}$ \\
\hline 0.2 & 0.0 & $40.5 \pm 13.3 \mathrm{a}$ & $9.5 \pm 4.8 \mathrm{ab}$ & $29.0 \pm 0.5 \mathrm{a}$ & $21.0 \pm 12.4 \mathrm{c}$ \\
\hline 1.0 & 0.0 & $18.1 \pm 11.7 \mathrm{abc}$ & $33.3 \pm 17.2 \mathrm{a}$ & $19.1 \pm 12.6 \mathrm{a}$ & $29.5 \pm 17.3 b c$ \\
\hline 0.1 & 0.1 & $36.7 \pm 14.0 \mathrm{ab}$ & $16.2 \pm 8.5 \mathrm{ab}$ & $12.9 \pm 8.4 \mathrm{a}$ & $34.3 \pm 13.5 \mathrm{bc}$ \\
\hline 0.2 & 0.1 & $11.4 \pm 5.9 \mathrm{bc}$ & $36.7 \pm 18.2 \mathrm{a}$ & $16.2 \pm 1.9 \mathrm{a}$ & $35.7 \pm 10.9 \mathrm{bc}$ \\
\hline 1.0 & 0.1 & $14.3 \pm 14.3 b c$ & $31.9 \pm 13.7 \mathrm{a}$ & $20.0 \pm 20.0 \mathrm{a}$ & $33.8 \pm 20.7 b c$ \\
\hline
\end{tabular}

${ }^{2}$ Basal medium contained MS salts, $100 \mathrm{mg} \cdot \mathrm{L}^{-1}$ myo-inositol, $30 \mathrm{~g} \cdot \mathrm{L}^{-1}$ sucrose, $170 \mathrm{mg} \cdot \mathrm{L}^{-1} \mathrm{NaH}_{2} \mathrm{PO}_{4}$, and $8.6 \mathrm{~g} \cdot \mathrm{L}^{-1}$ agar; the $\mathrm{pH}$ was adjusted to 5.7 before autoclaving.

${ }^{\mathrm{y}}$ Percentage data were arc sine transformed before analysis of variance; means \pm SES within a column followed by different letters indicate significant differences according to least significant difference multiple range test at $P<0.05$. Data are mean of three independent experiments.

containing BA (Table 1). In media containing both BA and NAA, the effect of BA on bud multiplication increased with concentration, with $1 \mathrm{mg} \cdot \mathrm{L}^{-1} \mathrm{BA}$ showing the best multiplication rates. By comparison, lower concentrations of BA $\left(0.1\right.$ and $\left.0.2 \mathrm{mg} \cdot \mathrm{L}^{-1}\right)$ caused significant bud elongation but not bud multiplication (Table 1). Considering the various effects on culture initiation, the combination of $1.0 \mathrm{mg} \cdot \mathrm{L}^{-1} \mathrm{BA}$ and $0.1 \mathrm{mg} \cdot \mathrm{L}^{-1} \mathrm{NAA}$ was chosen for further comparison with media containing $m \mathrm{~T}$ or $m \mathrm{TR}$ as the cytokinin.

Cytokinins show different levels of biological activities: $m \mathrm{TR}=$ zeatin $>$ benzyladenine riboside $(\mathrm{BAR})>$ ortho-topolin riboside $(o \mathrm{TR})=$ para -topolin riboside $(p \mathrm{TR})$ (Kamínek et al., 1987). Meta-topolin ( $m$ T) was slightly more active than $m \mathrm{TR}$ in wheat senescence and tobacco callus bioassays (Werbrouck et al., 1996). According to previous studies, $m \mathrm{~T}$ is considered the most active of the natural aromatic cytokinins; when used instead of the widely used BA, it can eliminate high callus formation rates, necrosis, and negative effects at the rooting stage (Bandaralage et al., 2015). In this study, we compared $\mathrm{BA}, m \mathrm{~T}$, and $m \mathrm{TR}$ during in vitro bud elongation of passion fruit nodal segments. The rates of bud multiplication, callus formation, and bud browning was not significantly different among the three aromatic cytokinins at the same concentration (1 $\mathrm{mg} \cdot \mathrm{L}^{-1}$; Table 2 ), but there was a big difference in appearance of the explants after 6 weeks (Fig. 2). Most explants cultured on the BA medium formed a rosette, even after transferring to PGR-free medium for 2-3 intervals of subculturing. Buds cultured on medium supplemented with $m \mathrm{~T}$ or $m \mathrm{TR}$ grew sustainably and elongated for 4 weeks. Explants grown on the $m \mathrm{TR}$ medium had larger leaves and an increased number of nodes on the stem (Fig. 2C). After transfer to the PA2L medium, shoots had fully expanded leaves and vigorous roots after 8 weeks. The average plant height was $8.4 \pm 2.6 \mathrm{~cm}$, and plants had an average of $11.6 \pm 2.6$ nodes per plantlet. The average in vitro rooting rate was $88.1 \pm$
$0.1 \%$. The average number of in vitro roots per plantlet was $5.4 \pm 3.1$, and the length of the longest root averaged $5.6 \pm 2.4 \mathrm{~cm}$. These plantlets could be further cut to produce one node that could be brought back into culture to repeat the process again. During 4-5 years of in vitro culture, no somaclonal variation was observed.

Plants derived from one round of multiplication (4 weeks) (Fig. 3A) and one subculture in PA2L medium for 8 weeks (Fig. 3B) were then transplanted to the greenhouse for another 8 weeks for acclimatization (Fig. 3C) before transfer to the field (Fig. 3D). Plants had flower buds 4 months after planting in the field, and the flower morphology were normal (Fig. 3E and F). Flowers were open-pollinated by bees in the field and showed a normal fruit set (Fig. 3G). Mature fruits naturally dropped on the net and had a purple-red peel and oval shape (Fig. $3 \mathrm{H}$ ). In the present study, a simple and reliable protocol for establishing nodal segment explants of the passion fruit cultivar Tainung No. 1 
Table 2. Effects of BA, NAA, and topolins on the culture of nodal segments in 'Tainung No. 1' passion fruit.

\begin{tabular}{lcccc}
\hline Cytokinin $^{\mathrm{z}}$ & Expanded leaves $(\%)^{\mathrm{y}}$ & Bud multiplication (\%) & Callus formation (\%) & Bud browning (\%) \\
\hline 0 & $16.7 \pm 8.5 \mathrm{a}$ & $1.7 \pm 1.7 \mathrm{~b}$ & $0.0 \pm 0.0 \mathrm{a}$ & $81.7 \pm 7.5 \mathrm{a}$ \\
$1 \mathrm{mg} \cdot \mathrm{L}^{-1} \mathrm{BA}$ & $15.1 \pm 8.3 \mathrm{a}$ & $47.5 \pm 13.1 \mathrm{a}$ & $4.8 \pm 4.8 \mathrm{a}$ & $32.6 \pm 5.4 \mathrm{~b}$ \\
$1 \mathrm{mg} \cdot \mathrm{L}^{-1} \mathrm{mT}$ & $16.1 \pm 9.6 \mathrm{a}$ & $39.6 \pm 23.0 \mathrm{a}$ & $0.0 \pm 0.0 \mathrm{a}$ & \\
$1 \mathrm{mg} \cdot \mathrm{L}^{-1} \mathrm{mTR}$ & $17.4 \pm 3.2 \mathrm{a}$ & $51.0 \pm 7.3 \mathrm{a}$ & $0.0 \pm 0.0 \mathrm{a}$ & $31.3 \pm 13.9 \mathrm{~b}$ \\
\hline
\end{tabular}

${ }^{\mathrm{z}}$ Basal medium contains MS salts, $100 \mathrm{mg} \cdot \mathrm{L}^{-1}$ myo-inositol, $30 \mathrm{~g} \cdot \mathrm{L}^{-1}$ sucrose, $170 \mathrm{mg} \cdot \mathrm{L}^{-1} \mathrm{NaH}_{2} \mathrm{PO}_{4}, 0.1 \mathrm{mg} \cdot \mathrm{L}^{-1} \mathrm{NAA}, 8.6 \mathrm{~g} \cdot \mathrm{L}^{-1}$ agar; the pH was adjusted to 5.7 before autoclaving. $\mathrm{BA}=$ benzyladenine; $m \mathrm{~T}=$ meta-topolin; $m \mathrm{TR}=$ meta-topolin riboside.

${ }^{\mathrm{y}}$ Percentage data were arc sine transformed before analysis of variance; means \pm sEs within a column followed by different letters indicate significant differences according to least significant difference multiple range test at $P<0.05$. Data are mean of three independent experiments.
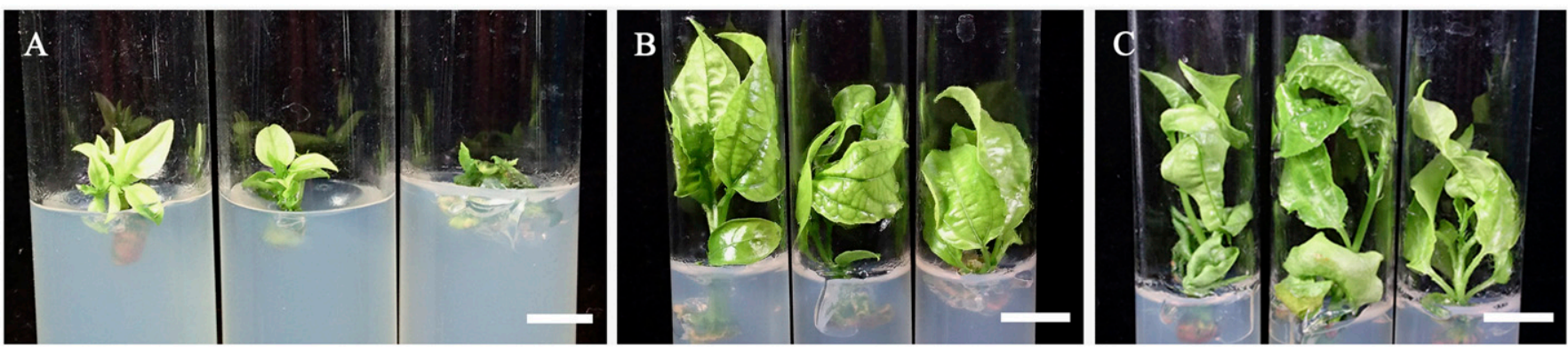

Fig. 2. Nodal segments were cultured on medium supplemented with one of three cytokinins for 6 weeks. (A) $1 \mathrm{mg} \cdot \mathrm{L}^{-1} \mathrm{BA} ;(\mathbf{B}) 1 \mathrm{mg} \cdot \mathrm{L}^{-1} \mathrm{meta}$-topolin; (C) 1 $\mathrm{mg} \cdot \mathrm{L}^{-1}$ meta-topolin riboside. Scale bars $=0.7 \mathrm{~cm}(\mathbf{A}), 1 \mathrm{~cm}(\mathbf{B})$, and $1 \mathrm{~cm}(\mathbf{C})$.
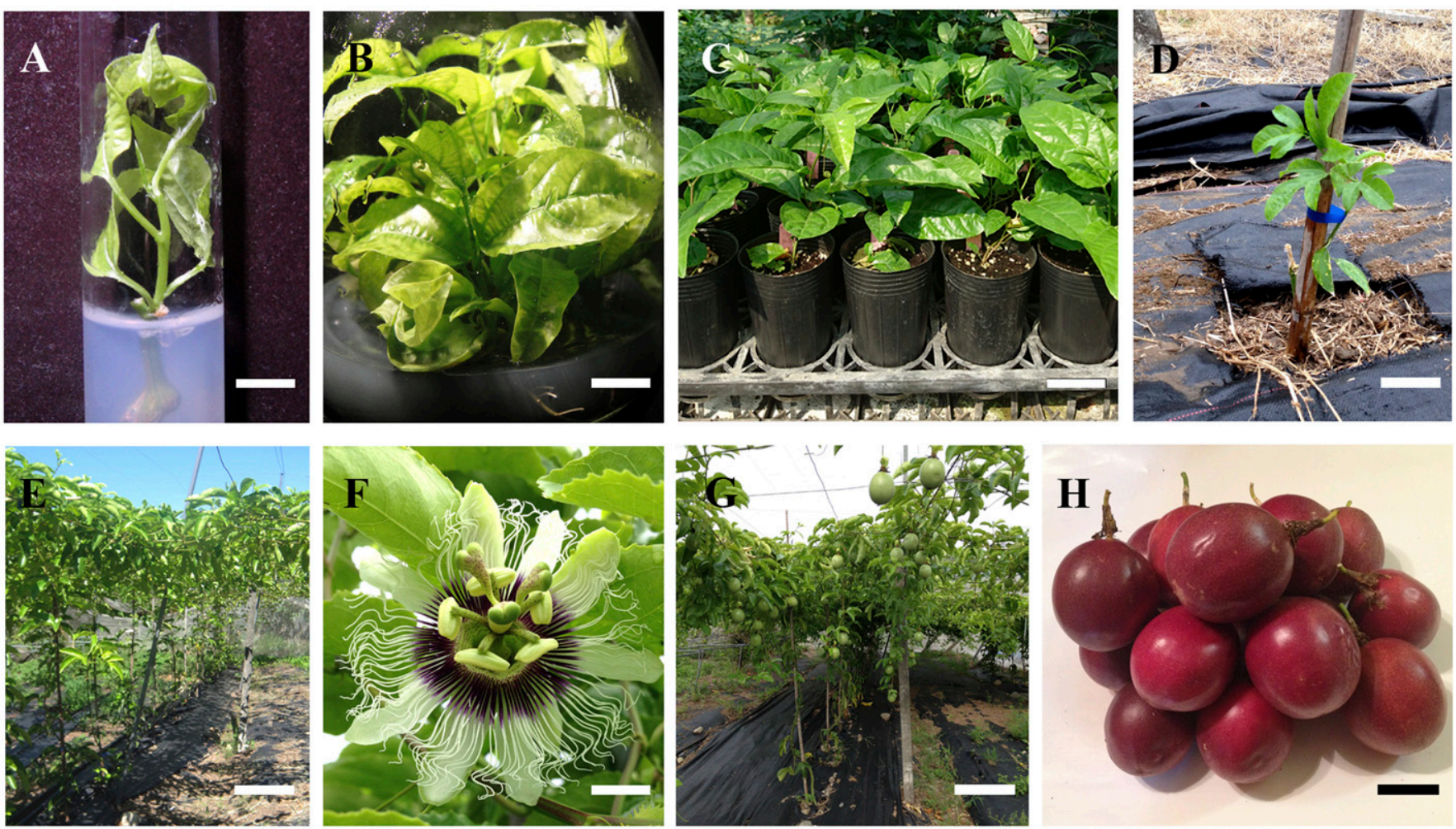

Fig. 3. Nodal segments of 'Tainung No. 1' passion fruit pictured during in vitro culture, acclimation, flowering, and fruit set in the field. (A) Elongated shoot from nodal segment cultured on a $m$ TR medium $($ bar $=8.6 \mathrm{~mm})$. (B) Healthy plantlets with fully expanded leaves and vigorous roots $($ bar $=1.6 \mathrm{~cm})$. $(\mathbf{C})$ Plantlets acclimated in a greenhouse (bar $=5.4 \mathrm{~cm})$. (D) Plant after transfer from greenhouse to the field $(\mathrm{bar}=8.8 \mathrm{~cm})$. (E) Plants with flower buds 4 months after planting in soil $(\mathrm{bar}=52.2 \mathrm{~cm})$. $(\mathbf{F})$ Open flower with normal shape and structures $(\mathrm{bar}=1.1 \mathrm{~cm})$. $(\mathbf{G})$ Flowers were pollinated by bees and showed normal fruit set $(\mathrm{bar}=41.4 \mathrm{~cm}) .(\mathbf{H})$ Mature fruit had normal color and shape $(\mathrm{bar}=3.2 \mathrm{~cm})$.

was established using the $m$ TR medium for node-bud elongation and the PGR-free medium for spontaneous rooting.

Numerous studies have discussed the promising of using $m \mathrm{~T}$ in many tissue culture systems (Aremu et al., 2014; Bairu et al.,
2006; Benmahioul et al., 2012; Bogaert et al., 2006; Lata et al., 2016; Werbrouck et al., 1996). Using $m$ TR improved the survival rate of potato cultures (Baroja-Fernández et al., 2002), proved to be better than BA in terms of multiplication rate and quality of shoots in
Baleria greenii (Amoo et al., 2011), and promoted the shoot multiplication rate over an equimolar concentration of BA in banana culture (Bairu et al., 2008). The superiority of $m \mathrm{~T}$ and its derivatives over BA has been attributed to its faster translocation in plant 
Table 3. Growth and development of nodal segments after $30 \mathrm{~d}$ of growth under different light qualities (LEDs) on shoot initiation (SI) medium.

\begin{tabular}{lcccc}
\hline Treatment $^{\mathrm{z}}$ & Bud no. $^{\mathrm{y}}$ & Leaf no. & Tendril no. & Callus formation (\%) $^{\mathrm{x}}$ \\
\hline CW & $1.3 \mathrm{ab}$ & $2.7 \mathrm{a}$ & $0.1 \mathrm{a}$ & $22.5 \mathrm{ab}$ \\
9B & $1.3 \mathrm{a}$ & $2.2 \mathrm{a}$ & $0.0 \mathrm{~b}$ & $15.0 \mathrm{~b}$ \\
3R3B3IR & $1.1 \mathrm{ab}$ & $2.4 \mathrm{a}$ & $0.0 \mathrm{~b}$ & $15.0 \mathrm{~b}$ \\
7R1G1B & $1.2 \mathrm{ab}$ & $2.6 \mathrm{a}$ & $0.0 \mathrm{~b}$ & $2.5 \mathrm{ab}$ \\
WW & $1.1 \mathrm{ab}$ & $2.4 \mathrm{a}$ & $0.0 \mathrm{~b}$ & $30.0 \mathrm{ab}$ \\
9R & $1.1 \mathrm{ab}$ & $2.3 \mathrm{a}$ & $0.0 \mathrm{~b}$ & $40.0 \mathrm{a}$ \\
8R1B & $1.0 \mathrm{~b}$ & $2.4 \mathrm{a}$ & $0.0 \mathrm{~b}$ & $25.0 \mathrm{ab}$ \\
7R1B1IR & $1.2 \mathrm{ab}$ & $2.5 \mathrm{a}$ & $0.0 \mathrm{~b}$ & $22.5 \mathrm{ab}$ \\
\hline
\end{tabular}

${ }^{\mathrm{z}}$ Light was provided by a combination of blue (B), green (G), red (R), and infrared (IR) LEDs. Cool white light (CW) and warm white light (WW) were of a spectrum like that of daylight.

${ }^{\mathrm{y}}$ Five nodal segments in each vessel supplemented with SI medium, $1 \mathrm{mg} \cdot \mathrm{L}^{-1}$ meta-topolin riboside $(m \mathrm{TR})$, and $0.1 \mathrm{mg} \cdot \mathrm{L}^{-1} \mathrm{NAA}$. Explants were maintained at $25 \pm 1{ }^{\circ} \mathrm{C}$ under a 12 -h photoperiod at a photosynthetic photon flux density of $42 \mu \mathrm{mol} \cdot \mathrm{m}^{-2} \cdot \mathrm{s}^{-1}$.

${ }^{x}$ Percentage data were arc sine transformed before analysis of variance; means \pm SES within a column followed by different letters indicate significant differences according to least significant difference multiple range test at $P<0.05$. Data are mean of three independent experiments.

Table 4. Various LED light qualities had long-lasting effects on plant growth and leaf chlorophyll content in nodal segments after induction to subculture at 8 weeks in 'Tainung No. 1' passion fruit.

\begin{tabular}{lccccccccc}
\hline Treatment $^{2}$ & Plant ht $(\mathrm{cm})^{\mathrm{y}}$ & Node no. & Leaf no. & Root no. & Max. root length $(\mathrm{cm})$ & Lateral bud no. & chl a $\left(\mathrm{mg} \cdot \mathrm{g}^{-1}\right)$ & ${\mathrm{chl} \mathrm{b}\left(\mathrm{mg} \cdot \mathrm{g}^{-1}\right)}^{\text {Total chl }\left(\mathrm{mg} \cdot \mathrm{g}^{-1}\right)}$ \\
\hline CK & $5.4 \mathrm{bc}$ & $9.2 \mathrm{a}$ & $7.1 \mathrm{a}$ & $4.3 \mathrm{a}$ & $3.3 \mathrm{~b}$ & $0.0 \mathrm{a}$ & $0.86 \mathrm{~b}$ & $0.28 \mathrm{~d}$ \\
CW & $3.1 \mathrm{~d}$ & $8.0 \mathrm{a}$ & $6.8 \mathrm{a}$ & $1.3 \mathrm{bc}$ & $0.1 \mathrm{c}$ & $0.3 \mathrm{a}$ & $1.54 \mathrm{ab}$ & $0.57 \mathrm{bc}$ & $2.14 \mathrm{~d}$ \\
9B & $5.5 \mathrm{bc}$ & $8.8 \mathrm{a}$ & $6.7 \mathrm{a}$ & $3.7 \mathrm{ab}$ & $3.3 \mathrm{~b}$ & $0.7 \mathrm{a}$ & $1.24 \mathrm{ab}$ & $0.41 \mathrm{~cd}$ & $1.64 \mathrm{cde}$ \\
3R3B3IR & $7.2 \mathrm{a}$ & $8.8 \mathrm{a}$ & $6.8 \mathrm{a}$ & $4.8 \mathrm{a}$ & $2.6 \mathrm{~b}$ & $0.0 \mathrm{a}$ & $0.82 \mathrm{~b}$ & $0.24 \mathrm{~d}$ & $1.05 \mathrm{~d}$ \\
WW & $4.1 \mathrm{~cd}$ & $7.3 \mathrm{a}$ & $4.3 \mathrm{~b}$ & $0.3 \mathrm{c}$ & $0.0 \mathrm{c}$ & $0.2 \mathrm{a}$ & $1.30 \mathrm{ab}$ & $0.55 \mathrm{bc}$ & $1.84 \mathrm{bcd}$ \\
9R & $7.2 \mathrm{a}$ & $8.5 \mathrm{a}$ & $7.5 \mathrm{a}$ & $5.5 \mathrm{a}$ & $5.3 \mathrm{a}$ & $0.0 \mathrm{a}$ & $1.86 \mathrm{a}$ & $0.86 \mathrm{a}$ & $2.71 \mathrm{a}$ \\
8R1B & $7.2 \mathrm{a}$ & $8.0 \mathrm{a}$ & $6.3 \mathrm{ab}$ & $4.0 \mathrm{ab}$ & $3.0 \mathrm{~b}$ & $0.3 \mathrm{a}$ & $1.83 \mathrm{a}$ & $0.81 \mathrm{ab}$ & $2.63 \mathrm{ab}$ \\
7R1B1IR & $5.9 \mathrm{ab}$ & $8.3 \mathrm{a}$ & $7.0 \mathrm{a}$ & $3.3 \mathrm{ab}$ & $2.4 \mathrm{~b}$ & $0.5 \mathrm{a}$ & $1.46 \mathrm{a}$ & $0.51 \mathrm{~cd}$ & $1.97 \mathrm{abc}$ \\
\hline
\end{tabular}

${ }^{\mathrm{z}}$ Light was provided by LED chips, except for the CK treatment. A combination of blue (B), green (G), red (R), and infrared (IR) LEDs was used as light source in each treatment. Cool white light $(\mathrm{CW})$ and warm white light $(\mathrm{WW})$ were of a spectrum like that of daylight. $\mathrm{CK}=$ nodal segments were cultured in a culture room with daylight fluorescent tubes at a light intensity of $55.6 \mu \mathrm{mol} \cdot \mathrm{m}^{-2} \cdot \mathrm{s}^{-1}$.

${ }^{\mathrm{y}}$ The nodal segments were cultured in the tissue culture vessels with LED chips mounted on their lips, while the CK treatment was cultured in a glass flask in a culture room. After 4 weeks of light treatment, nodal segments were all transferred to PA2L medium for another 8 weeks in a culture room with daylight fluorescent tubes. Mean values in the same column with different letter(s) indicate significant differences according to least significant difference multiple range test at $P<0.05$. Data are mean of a total of six independent plants collected from two independent experiments.
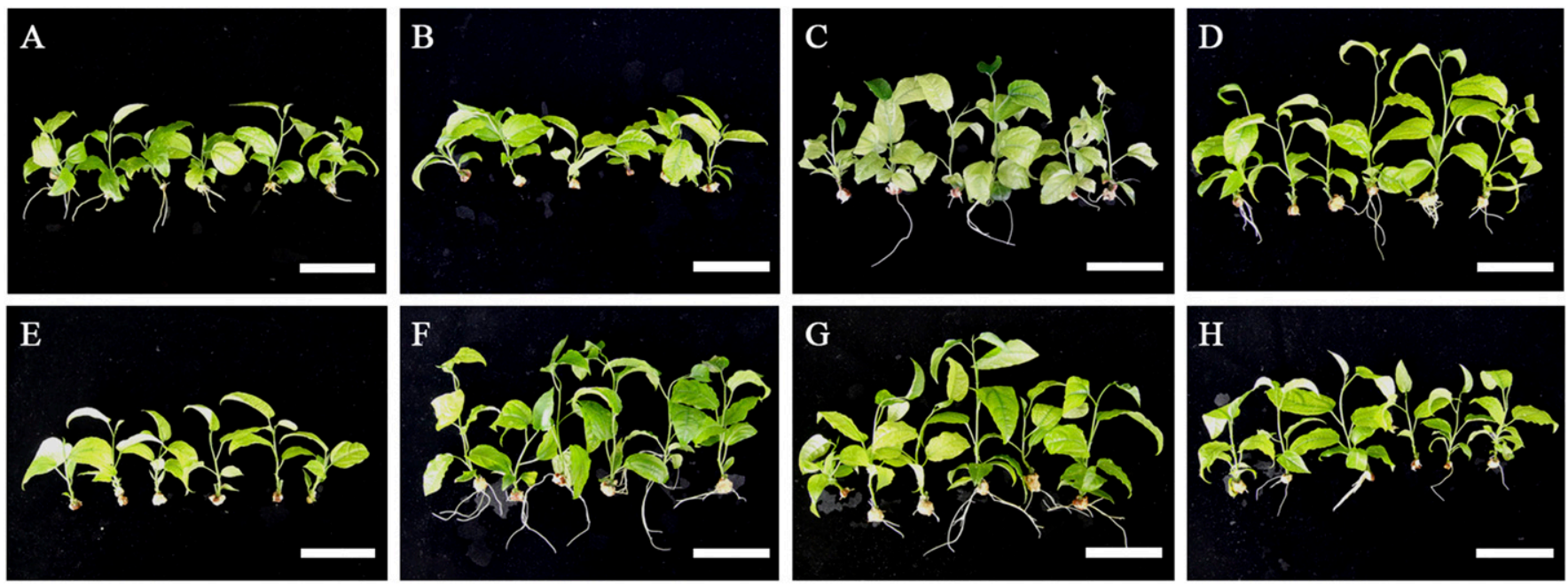

Fig. 4. The morphology of nodal segments cultured on a medium containing meta-topolin riboside in various light qualities for 4 weeks and then subcultured on a growth medium without plant growth regulators for another 8 weeks. (A) $\mathrm{CK}=$ explants cultured in a culture room with daylight fluorescent tubes (bar $=5.4$ $\mathrm{cm}) .(\mathbf{B}) \mathrm{CW}=\mathrm{cool}$ white light $(\mathrm{bar}=4.4 \mathrm{~cm}) .(\mathbf{C}) 9 \mathrm{~B}(\mathrm{bar}=5.2 \mathrm{~cm}) .(\mathbf{D}) 3 \mathrm{R} 3 \mathrm{~B} 3 \mathrm{IR}(\mathrm{bar}=4.6 \mathrm{~cm}) .(\mathbf{E}) \mathrm{WW}=$ warm white light $(\mathrm{bar}=4.8 \mathrm{~cm}) .(\mathbf{F}) 9 \mathrm{R}(\mathrm{bar}=$ $4.7 \mathrm{~cm})$. (G) $8 \mathrm{R} 1 \mathrm{~B}(\mathrm{bar}=4.5 \mathrm{~cm}) .(\mathbf{H}) 7 \mathrm{R} 1 \mathrm{~B} 1 \mathrm{IR}(\mathrm{bar}=4.9 \mathrm{~cm})$.

tissue, which prevents localized accumulation, its different affinity for receptors, and the formation and reversible sequestration of its $O$-glucoside metabolites (Amoo et al., 2012; Aremu et al., 2012a; Kamínek et al., 1987; Mok et al., 2005; Strnad 1997; Subbaraj, 2011; Werbrouck et al., 1996).

Light quality affects plantlet growth and the chlorophyll content of explants during in vitro culture. While establishing the culture procedure for nodal segments of passion fruit using $1 \mathrm{mg} \cdot \mathrm{L}^{-1} \mathrm{mTR}$ as the cytokinin in the initial medium, the leaves of plantlets were yellowish-green in color (Figs. 2C and 3B), although this did not affect the survival rate, and new leaves became normal in the greenhouse (Fig. 3C). To increase the appearance of the plantlets, we investigated if changing the supplied light quality, an important environmental factor in tissue culture, could improve the leaf color. Nodal segments cultured in various LED spectra showed no differences in leaf numbers. A significant difference in the number of buds per segment was seen between the 9B and 8R1B treatments, however, not between $9 \mathrm{~B}$ and the other treatments. Tendrils were only observed 
under the CW treatment. Increasing the proportion of red light resulted in fewer buds and more calli at the node base. Monochromatic red LED (9R) significant enhanced the callus formation compared with the $9 \mathrm{~B}$ and 3R3B3IR treatments (Table 3).

The light quality used during culture initiation also manifested in subsequent plant growth after transfer to the PGR-free medium in the tissue culture room with normal daylight fluorescent tubes. Red LED during initiation increased the shoot length, root number, maximum root length, and chlorophyll content (including chl a and chl b) 8 weeks after transferring to the PGR-free medium. The 3R3B3IR LED combination promoted shoot growth and root number but resulted in shorter root length and the lowest chlorophyll content. The CW and WW treatments significantly inhibited root length compared with the other LED treatments. There was no difference in the numbers of nodes between the treatments, which indicated that internode elongation leads to the recorded increase in plant height in the red light condition (Table 4; Fig. 4). LED treatments yielding higher chlorophyll content are generally associated with improved shoot growth (Liu et al., 2006). However, the responses to different spectral qualities provided by LEDs vary according to plant species (Gupta and Agarwal, 2017). In in vitro-cultured Pfaffia glomerate, an equal ratio of red and blue light enhanced the biomass and 20-hydroxyecdysone content (Silva et al., 2020). In contrast, in grape and blueberry, a high proportion of red LEDs accelerated the elongation of regenerated shoots, but blue LED treatment increased the chlorophyll content (Hung et al., 2016; Poudel et al., 2008). Other research showed that blue light promoted stem elongation of eggplant and sunflower seedlings and suppressed stem elongation of leaf lettuce and tomato (Hirai et al., 2006; Li et al., 2017; Mochizuki et al., 2019). Conversely, red LED treatment enhanced chlorophyll content in the shoot culture of banana (Vieira et al., 2015) and Rehmannia glutinosa (Manivannan et al., 2015). When leafy single-node cuttings of Vitis vinifera 'Manicure Finger' were cultured in vitro under red LED light, stem elongation, leaf growth, and chlorophyll reduction, all associated with shade-avoidance syndrome (SAS), were the primary responses (Li et al., 2017). Red light may promote stem growth by regulating the biosynthesis of gibberellic acid in Norway spruce seedlings (Ouyang et al., 2015), or induce the expression of an auxin inhibitor gene to promote stem and root lengthening in grape (Li et al., 2017). Red light also increased the activity of Phenylalanine ammonia lyase (PAL) in Dianthus caryophyllus (Manivannan et al., 2017) and the total lignin content in Triticum aestivum (Dong et al., 2014).

Promotion of in vitro root induction and development by red LED treatments has been reported for various plant species, including Tripterospermum japonicum (Moon et al., 2006), grape (Poudel et al., 2008), banana
(Wilken et al., 2014), $R$. glutinosa (Manivannan et al., 2015), and Cunninghamia lanceolata (Xu et al., 2019). The interaction between light quality and cytokinin content in media on multiplication and growth was evaluated during in vitro culture of Myrtus communis L. The results indicated that the highest number of shoots was obtained under red LEDs with the lowest concentration of cytokinin in the media (Cioć et al., 2018). In this study, red LED illumination produced superior plantlets, marked by improvements in the in vitro shoot length, chlorophyll content, and leaf and root growth that also acclimatized at a high rate $(\approx 100 \%)$.

\section{Conclusion}

Passion fruit is an important fruit crop around the world. The demands on production and trade in passion fruits are gaining importance globally (Altendorf, 2018; Ramaiya et al., 2019). This growing global market and demand for high-quality plants is beyond the current commercial capacity to supply plants through germinating seeds or by grafting. Simultaneously, the production of passion fruit transplants by tissue culture is often limited by the problems of shoot clustering and leaf yellowing (Monteiro et al., 2000). In Taiwan, the main cultivar is Tainung No. 1, and grafted plants are used for commercial production of fruits both for internal markets and for export. In this study, we established a reliable node-bud proliferation system that uses $m \mathrm{TR}$ as the cytokinin, yielding a high rate of shoot elongation, and illumination with red light to improve plantlet quality. Plantlets rooted spontaneously in growth medium without auxin, thus avoiding an extra rooting step in the protocol. To the best of our knowledge, this is the first report on the use of topolins and various light qualities for in vitro propogation of Passiflora.

\section{Literature Cited}

Agarwal, A. and S. Dutta Gupta. 2016. Impact of light-emitting diodes (LEDs) and its potential on plant growth and development in controlledenvironment plant production system. Curr. Biotechnol. 5:28-43.

Altendorf, S. 2018. Minor tropical fruits-Mainstreaming a niche market, p. 67-75. In: Food OutlookBiannual Report on Global Food Markets. FAO, Rome. July 2018. <http://www.fao.org/fileadmin/ templates/est/COMM_MARKETS_MONITORING/ Tropical_Fruits/Documents/Minor_Tropical_ Fruits_FoodOutlook_1_2018.pdf>.

Amoo, S.O., A.O. Aremu, and J.V. Staden. 2012. In vitro plant regeneration, secondary metabolite production and antioxidant activity of micropropagated Aloe arborescens Mill. Plant Cell Tissue Organ Cult. 111:345-358.

Amoo, S.O., J.F. Finnie, and J.V. Staden. 2011. The role of meta-topolins in alleviating micropropagation problems. Plant Growth Regulat. 63:197-206

Aremu, A.O., L. Plačková, M.W. Bairu, O. Novák, L. Szüčová, K. Doležal, J.F. Finnie, and J.V. Staden. 2014. Endogenous cytokinin profiles of tissue-cultured and acclimatized 'Williams' bananas subjected to different aromatic cytokinin. Plant Sci. 214:88-98.
Aremu, A.O., M.W. Bairu, K. Doležal, H.F. Finnie, and J. Van Staden. 2012a. Topolins: A panacea to plant tissue culture challenges? Plant Cell Tissue Organ Cult. 108:1-16.

Aremu, A.O., M.W. Bairu, L. Szüčová, J.F. Finnie, and J. Van Staden. 2012b. The role of metatopolins on the photosynthetic pigment profiles and foliar structures of micropropagated 'Williams' bananas. J. Plant Physiol. 169:15301541.

Bairu, M.W., C.W. Fennell, and J.V. Staden. 2006. The effect of plant growth regulators on somaclonal variation in Cavendish banana (Musa AAA cv. 'Zelig'). Scientia Hort. 108:347-351.

Bairu, M.W., M.G. Kulkarni, R.A. Streèt, R.B. Mulaudzi, and J. Van Staden. 2009. Studies on seed germination, seedling growth, and in vitro shoot induction of Aloe ferox Mill., a commercially important species. HortScience 44:751-756.

Bairu, M.W., O. Novák, K. Doležal, and J. Van Staden. 2011. Changes in endogenous cytokinin profiles in micropropagated Harpagophytum procumbens in relation to shoot-tip necrosis and cytokinin treatment. Plant Growth Regulat. 63:105-114.

Bairu, M.W., W.A. Stirk, K. Dolezal, and J.V. Staden. 2007. Optimizing the micropropagation protocol for the endangered Aloe polyphylla: Can meta-topolin and its derivatives serve as replacement for benzyladenine and zeatin? Plant Cell Tissue Organ Cult. 90:15-23.

Bairu, M.W., W.A. Stirk, K. Doležal, and J.V. Staden. 2008. The role of topolins in micropropagation and somaclonal variation of banana cultivars 'Williams' and 'Grand Naine' (Musa spp. AAA). Plant Cell Tissue Organ Cult. 95:373-379.

Bandaralage, J.C.A.H., A. Hayward, C. O'Brien, and N. Mitter. 2015. Gibberellin and cytokinin in synergy for a rapid nodal multiplication system of avocado. Proceeding of the World Avocado Congress VIII, 95-98.

Baroja-Fernández, E., J. Aguirreolea, H. Martínková, J. Hanušd, and M. Strnad. 2002. Aromatic cytokinins in micropropagated potato plants. Plant Physiol. Biochem. 40:217-224.

Batista, D.S., S.H.S. Felipe, T.D. Silva, K.M. de Castro, T.C. Mamedes-Rodrigues, N.A. Miranda, A.M. Ríos-Ríos, D.V. Faria, E.A. Fortini, K. Chagas, G. Torres-Silva, A. Xavier, A.D. Arencibia, and W.C. Otoni. 2018. Light quality in plant tissue culture: Does it matter? In Vitro Cell. Dev. Biol. Plant 54:195-215.

Benmahioul, B., N. Dorion, M. Kaid-Harche, and F. Daguin. 2012. Micropropagation and ex vitro rooting of pistachio (Pistacia vera $\mathrm{L}$.) Plant Cell Tissue Organ Cult. 108:353-358.

Bogaert, I., S.V. Cauter, S.P.O. Werbrouck, and K. Doležal. 2006. New aromatic cytokinins can make the difference. Acta Hort. 725:265-270.

Bula, R.J., R.C. Morrow, T.W. Tibbits, and D.J. Barta. 1991. Light-emitting diodes as a radiation source for plants. HortScience 26:203205.

Chen, C.C., D.C. Agrawal, M.R. Lee, R.J. Lee, C.L. Kuo, C.R. Wu, H.S. Tsay, and H.C. Chang. 2016. Influence of LED lighting spectra on in vitro somatic embryogenesis and LC-MS analysis of chlorogenic acid and rutin in Peucedanum japonicum Thunb.: A medicinal herb. Bot. Stud. 57:e9, doi: 10.1186/s40529-016-0124-z.

Cioć, M., A. Szewczyk, M. Żupnik, A. Kalisz, and B. Pawłowska. 2018. LED lighting affects plant growth, morphogenesis and phytochemical contents of Myrtus communis L. in vitro. Plant Cell Tissue Organ Cult. 132:433-447. 
Compton, M.E. 1994. Statistical methods suitable for the analysis of plant tissue culture data. Plant Cell Tissue Organ Cult. 37:217-242.

Dong, C., Y. Fu, G. Liu, and H. Liu. 2014. Growth, photosynthetic characteristics, antioxidant capacity and biomass yield and quality of wheat (Triticum aestivum L.) exposed to LED light sources with different spectra combinations. J. Agron. Crop Sci. 200:219-230.

Dutta Gupta, S. and B. Jatothu. 2013. Fundamentals and applications of light-emitting diodes (LEDs) in in vitro plant growth and morphogenesis. Plant Biotechnol. Rep. 7:211-220.

Faleiro, F.G., N.T.V. Junqueira, T.G. Junghans, O.N. de Jesus, D. Miranda, and W.C. Otoni. 2019. Advances in passion fruit (Passiflora spp.) propagation. Rev. Bras. Frutic. Jaboticabal 41(2):e-155, doi: 10.1590/0100-29452019155.

Fang, W., C.C. Chen, Y.L. Lee, and M.Y. Chung. 2011. Development of LED lids for tissue culture lighting. Acta Hort. 907:397-402.

Gentile, A., M. Jàquez Gutiérrez, J. Martinez, A. Frattarelli, P. Nota, and E. Caboni. 2014. Effect of meta-topolin on micropropagation and adventitious shoot regeneration in Prunus rootstocks. Plant Cell Tissue Organ Cult. 118:373-381.

Gupta, S.D. and A. Agarwal. 2017. Influence of LED lighting on in vitro plant regeneration and associated cellular redox balance, p. 273-303. In: S.D. Gupta (ed.). Lighting emitting diodes for agriculture. Springer Nature Singapore Pte Ltd., Singapore.

Hirai, T., W. Amaki, and H. Watanabe. 2006. Effects of monochromatic light irradiation by LED on the internodal stem elongation of seedlings in eggplant, leaf lettuce and sunflower. J. SHITA 18:160-166. (In Japanese with English abstract).

Huh, Y.S., J.K. Lee, and S.Y. Nam. 2017. Effect of plant growth regulators and antioxidants on in vitro plant regeneration and callus induction from leaf explants of purple passion fruit (Passiflora edulis Sims). J. Plant Biotechnol. 44:335-342.

Hung, C.D., C.H. Hong, S.K. Kim, K.H. Lee, J.Y. Park, M.W. Nam, D.H. Choi, and H.I. Lee. 2016. LED light for in vitro and ex vitro efficient growth of economically important highbush blueberry (Vaccinium corymbosum L.). Acta Physiol. Plant. 38:152.

Huyluoglu, Z., M. Unal, and N.P. Unsal. 2008. Cytological evidences of the role of Metatopolin and Benzyladenin in barley root tips. Adv. Mol. Biol. 1:31-37.

Inskeep, W.P. and P.R. Bloom. 1985. Extinction coefficients of chlorophyll $a$ and $b$ in $N, N$ Dimethylformamide and $80 \%$ acetone. Plant Physiol. 77:483-485.

Kamínek, M., T. Vaněk, and V. Motyka. 1987. Cytokinin activities of $\mathrm{N}^{6}$-benzyladenosine derivatives hydroxylated on the side-chain phenyl ring. J. Plant Growth Regul. 6:113-120.

Kubalákova, M. and M. Strnad. 1992. The effects of aromatic cytokinins (populins) on micropropagation and regeneration of sugar beet in vitro. Biol. Plant. 34:578-579.

Lai, I.L., C.W. Lin, T.Y. Chen, and W.H. Hu. 2018. Micropropagation shortens the time to blooming of Begonia montaniformis $\times$ Begonia ningmingensis var. bella F1 Progeny. HortScience 53:1855-1861.

Lata, H., A. Chandra, N. Techen, I.A. Khan, and M.A. Elsohly. 2016. In vitro mass propagation of Cannabis sativa L.: A protocol refinement using novel aromatic cytokinin meta-topolin and the assessment of eco-physiological, biochemical and genetic fidelity of micropropagated plants. J. Appl. Res. Med. Aromat. Plants 3:18-26.
Lee, Y.I., W. Fang, and C.C. Chen. 2011. Effect of six different LED light qualities on the seedling growth of Paphiopedilum orchid in vitro. Acta Hort. 907:389-391.

Li, C.X., Z.G. Xu, R.Q. Dong, S.X. Chang, L.Z. Wang, M. Khalil-Ur-Rehman, and J.M. Tao. 2017. An RNA-seq analysis of grape plantlets grown in vitro reveals different responses to blue, green, red LED light, and white fluorescent light. Front. Plant Sci. 8:78.

Liu, Y., Y. Tong, Y. Zhu, H. Ding, and E.A. Smith. 2006. Leaf chlorophyll readings as an indicator for spinach yield and nutritional quality with different nitrogen fertilizer application. J. Plant Nutr. 29:1207-1217.

Manivannan, A., P. Soundararajan, Y.G. Park, H. Wei, S. Kim, and B.R. Jeong. 2017. Blue and red light-emitting diodes improve the growth and physiology of in vitro-grown carnations 'Green Beauty' and 'Purple Beauty'. Hort. Environ. Biotechnol. 58(1):12-20.

Manivannan, A., P. Soundararajan, N. Halimah, C.H. Ko, and B.R. Jeong. 2015. Blue LED light enhances growth, phytochemical contents, and antioxidant enzyme activities of Rehmannia glutinosa cultured in vitro. Hort. Environ. Biotechnol. 56(1):105-113.

Massa, G.D., H.H. Kim, R.M. Wheeler, and C.A. Mitchell. 2008. Plant productivity in response to LED lighting. HortScience 43:1951-1956.

Mikovski, A.I., N.T. da Silva, C.S. Souza, M.D. Machade, W.C. Otoni, I.F. Carvalho, D.I. Rocha, and M.L. Silva. 2019. Tissue culture and biotechnological techniques applied to passion fruit with ornamental potential: An overview. Ornam. Hort. 25(2):189-199.

Mirabbasi, S.M. and B. Hosseinpour. 2014. Prevention of shoot tip necrosis, hyperhydricity and callus production associated with in vitro shoot culture of Ulmus glabra. J. Nov. Appl. Sci. 3(6):683-689.

Mochizuki, Y., S. Sekiguchi, N. Horiuchi, T. Aung, and I. Ogiwara. 2019. Photosynthetic characteristics of individual strawberry (Fragaria $\times$ ananassa Duch.) leaves under short-distance lighting with blue, green, and red LED lights. HortScience 54:452-458.

Mok, M.C., R.C. Martin, P.I. Dobrev, R. Vanková, P.S. Ho, K. Yonekura-Sakakibara, H. Sakakibara, and D.W.S. Mok. 2005. Topolins and hydroxylated thidiazuron derivatives are substrates of cytokinin $O$-gulucosyltransferase with position specificity related to receptor recognition. Plant Physiol. 137:1057-1066.

Monteiro, A.C.B.A., E.N. Higashi, A.N. Gonçalves, and A.P.M. Rodriguez. 2000. A novel approach for the inorganic medium components for micropropagation of yellow passionfruit (Passiflora edulis Sims. f. flavicarpa Deg.). In Vitro Cell. Dev. Biol. Plant 36:527-531.

Moon, H.K., S.K. Park, Y.W. Kim, and C.S. Kim. 2006. Growth of Tsuru-rindo (Tripterospermum japonicum) cultured in vitro under various sources of light-emitting diode (LED) irradiation. J. Plant Biol. 49:174-179.

Moran, R. and D. Porath. 1980. Chlorophyll determination in intact tissue using $N, N$-Dimethylformamide. Plant Physiol. 65:478-479.

Moyo, M., J.F. Finnie, and J.V. Staden. 2012. Topolins in Pelargonium sidoides micropropagation: Do the new brooms really sweep cleaner? Plant Cell Tissue Organ Cult. 110:319-327.

Murashige, T. and F. Skoog. 1962. A revised medium for rapid growth and bioassays with tobacco tissue culture. Physiol. Plant. 15:473-479.

Mutui, T.M., H. Mibus, and M. Serek. 2012. Effect of meta-topolin on leaf senescence and rooting in Pelargonium $\times$ hortorum cuttings. Postharvest Biol. Technol. 63:107-110.

Ornellas, T.S., D. Werner, D.F. Holderbaum, R.F. Scherer, and M.P. Guerra. 2017. Effects of vitrofural, BAP and meta-topolin in the in vitro culture of Dendrocalamus asper. Acta Hort. 1155:285-292.

Otoni, W.C., D.P.L. Pinto, D.I. Rocha, L.M. Vieira, L.C.C. Dias, M.L. Silva, C.V.E. Silva, R.G. Lani, L.C. Silva, and F.A.O. Tanaka. 2013. Organogenesis and somatic embryogenesis in passionfruit (Passiflora spp.), p. 1-17. In: J. Aslam, O.S. Srivastava, and M.P. Sharma (eds.). Somatic embryogenesis and gene expression. Narosa Publishing House, New Delhi.

Ouyang, F., J.F. Mao, J. Wang, S. Zhang, and Y. Li. 2015. Transcriptom analysis reveals that red and blue light regulate growth and phytohormone metabolism in Norway Spruce [Picea abies (L.) Karst]. PLoS One 10:e0127896, doi: 10.1371/journal.pone.0127896.

Ożarowski, M. 2011. Influence of the physicochemical factors, plant growth regulators, elicitors and type of explants on callus cultures of medicinal climbers of Passiflora L. Herba Pol. 57:58-75.

Ożarowski, M. and B. Thiem. 2013. Progress in micropropagation of Passiflora spp. to produce medicinal plants: A mini review. Rev. Bras. Farmacogn. 23:937-947.

Pacheco, G., M.J. Simão, M.G. Vianna, R.O. Garcia, M.L.C. Vieira, and E. Mansur. 2016. In vitro conservation of Passiflora-A review. Scientia Hort. 211:305-311.

Palavan-Ünsal, N., S. Çağ, and E. Çetin. 2002a. Growth responses of excised radish cotyledos to meta-topolin. Can. J. Plant Sci. 82:191-194.

Palavan-Ünsal, N., S. Çağ, and E. Çetin. 2004. The role of meta-topolin in senescence of wheat leaf segments. J. Cell Mol. Biol. 3:23-31.

Palavan-Ünsal, N., S. Çağ, E. Çetin, and D. Büyüktunçer. 2002b. Retardation of senescence by meta-topolin in wheat leaves. J. Cell Mol. Biol. 1:101-108.

Parris, J.K., D.H. Touchell, T.G. Ranney, and J. Adelberg. 2012. Basal salt composition, cytokinins, and phenolic binding agents influence in vitro growth and ex vitro establishment of Magnolia 'Ann'. HortScience 47:1625-1629.

Poudel, P.R., I. Kataoka, and R. Mochioka. 2008. Effect of red- and blue-light-emitting diodes on growth and morphogenesis of grapes. Plant Cell Tissue Organ Cult. 92:147-153.

Ragavendran, C., D. Kamalanathan, G. Reena, and D. Natarajan. 2012. In vitro propagation of nodal and shoot tip explants of Passiflora foetida L., an exotic medicinal plant. Asian J. Plant Sci. Res. 2(6):707-711.

Ramaiya, S.D., J.S. Bujang, and M.H. Zakaria. 2019. Physicochemical, fatty acid and antioxidant properties of passion fruit (Passiflora species) seed oil. Pakistan J. Nutrit. 18:421-429.

Ramírez-Mosqueda, M.A., L.G. Iglesias-Andreu, and J.R. Bautista-Aguilar. 2016. The effect of light quality on growth and development of in vitro plantlet of Stevia rebaudiana Bertoni. Sugar Tech, doi: 10.117/s12355-016-0459-5.

Rocha, D.I., C.C. Monte-Bello, and M.C. Dornelas. 2015. Alternative induction of de novo shoot organogenesis or somatic embryogenesis from in vitro cultures of mature zygotic embryos of passion fruit (Passiflora edulis Sims) is modulated by the ratio between auxin and cytokinin in the medium. Plant Cell Tissue Organ Cult. 120:1087-1098.

Rocha, D.I., D.S. Batista, F.G. Faleiro, M. Rogalski, L.M. Ribeiro, M.O. Mercadante-Simões, R. Yockteng, M.L. Silva, W.S. Soares, M.V.M. 
Pinheiro, T.G. Pacheco, A.S. Lopes, L.F. Viccini, and W.C. Otoni. 2020. Passion fruit: Passiflora spp., p. 381-408. In: R.A. Litz, F. Pliego-Alfaro, and J.I. Hormaza (eds.). Biotechnology of fruit and nut crops, 2nd ed. CABI, Wallingford, UK.

Silva, T.D., D.S. Batista, E.A. Fortini, K.M. Castro, S.H.S. Felipe, A.M. Fernandes, R.M.J. Sousa, K. Chagas, J.V.S. Silva, L.N.F. Correia, L.M. Farias, J.P.C.L. Leite, D.I. Rocha, and W.C. Otoni. 2020. Blue and red light affects morphogenesis and 20-hydroxydecdisone content of in vitro Pfaffia glomerata accession. J. Photochem. Photobiol. 203:111761, doi: 10.1016/ j.jphotobiol.2019.111761.

Strnad, M. 1997. The aromatic cytokinins. Physiol. Plant. 101:674-688.
Strnad, M., J. Hanuš, T. Vaněk, M. Kamínek, J.A. Ballantine, B. Fussell, and D.E. Hanke. 1997. Meta-topolin, a highly active aromatic cytokinin from poplar leaves (Populus $\times$ candaensis Moench., cv. Robusta). Phytochemistry 45(2):213-218.

Subbaraj, A.K. 2011. Topolins: Current research status and applications. IJBSM 2(1):10-25.

Ulmer, T. and J.M. MacDougal. 2004. Passiflora, passion flowers of the world. Timber Press, Cambridge.

Vieira, L.D.N., H.P. de Freitas Fraga, K.G. dos Anjos, C.C. Puttkammer, R.F. Scherer, D.A. da Silva, and M.P. Guerra. 2015. Light-emitting diodes (LED) increase the stomata formation and chlorophyll content in Musa acuminata (AAA) 'Nanicão Curupá' in vitro plantlets. Theor. Exp. Plant Physiol. 27(2):91-98.
Werbrouck, S.P.O., M. Staden, H.A. Van Onckelen, and P.C. Debergh. 1996. Meta-topolin, an alternative to benzyladenine in tissue culture? Physiol. Plant. 98:291-297.

Wilken, D., E.J. Gonzalez, A. Gerth, R. GómezKosky, A. Schumann, and D. Claus. 2014. Effect of immersion system, lighting, and TIS designs on biomass increase in micropropagation banana (Musa spp. cv. 'Grande naine' AAA). In Vitro Cell. Dev. Biol. Plant 50: 582-589.

Xu, Y., Y.U. Liang, and M. Yang. 2019. Effects of composite LED light on root growth and antioxidant capacity of Cunninghamia lanceolata tissue culture seedlings. Sci. Rep. 9:9766, doi: 10.1038/s41598-019-46139-2. 